\title{
Analisis Strategi Pengembangan Biogas Sebagai Energi Alternatif Rumah Tangga Dengan Memanfaatkan Limbah Ternak Kotoran Sapi
}

\section{Strategy Analysis Of Biogas Development As Domestic Alternative Energy By Utilizing Cow Manure}

\author{
Septia Ningrum $^{1}$, Supriyadi ${ }^{1}$, dan Zulkarnain ${ }^{1 *}$ \\ ${ }^{1 *}$ Sekolah Tinggi Ilmu Pertanian (STIPER) Dharma Wacana, Kota Metro, Indonesia \\ *E-mail : zulfadhilalzabir@gmail.com
}

\begin{abstract}
The development of alternative energy which is sourced from cow manure has good prospect to fulfill domestic needs of society. There is one way that can be done by turning farm waste, especially cow manure, to alternative energy as the substitution of fuel in form of biogas. The aim of the study was to analyze developing strategy of biogas as domestic alternative energy by making use of cow manure in Sari Bhakti village, District of Seputih Banyak in Region of Lampung Tengah. The method used in this study was SWOT analysis. Respondents were selected purposively (purposive sampling) from Sari Bhakti village, district of Seputih Banyak with the total sample were 25 cow farmers and 4 experts who have the competence in developing biogas from cow manure. The research finding showed that based on the result analysis of SWOT metrics, recommendation that should be given is 'progressive strategy'. Alternative strategy that can be applied is by utilizing cow farming group to get support from the governance in order to decrease the pollution of environment and to increase the prosperity of society, moreover, increasing socialization of biogas as domestic alternative energy is essential to increase the role of farming group in innovating technology of alternative energy.
\end{abstract}

Keywords: Biogas, Alternative Energy Household, Waste, Development, Strategy, Livestock.

Disubmit: 04 Juni 2018; Diterima : 24 Juli 2018; Disetujui : 29 September 2018;

\section{PENDAHULUAN}

Keterbatasan sumber daya energi yang dimiliki Indonesia menjadi salah satu kendala yang menghambat laju pertumbuhan ekonomi (Sagala, 2000) hal ini menunjukkan bahwa sumber daya energi mempunyai peran yang sangat penting bagi pembangunan ekonomi nasional. Meskipun Indonesia merupakan salah satu negara penghasil minyak dan gas, namun berkurangnya cadangan minyak, penghapusan subsidi menyebabkan harga minyak naik dan kualitas lingkungan menurun akibat penggunaan bahan bakar fosil yang berlebihan.

Upaya pengembangan energi alternatif dari pemerintah mendorong usaha pengembangan energi terbarukan yang bersumber dari peternakan. Peternakan sapi merupakan salah satu usaha yang sangat berpotensi tinggi dalam pengembangan energi alternatif. Pemanfaatan sumber energi alternatif dari limbah ternak memberikan banyak keuntungan yaitu bahan bakar yang berkualitas dan tidak berbau, serta menghasilkan (Haryati, 2006). Oleh karena itu, pemanfaatan sumber-sumber energi alternatif yang terbarukan dan ramah lingkungan menjadi pilihan seperti limbah ternak peternakan. Terdapat tiga energi alternatif (renewable reseource) yang potensial untuk dikembangkan di Indonesia yaitu biofuel nyamplung, 
panas bumi, energi surya dan biogas (Mulyana, 2013). Salah satu usaha yang dapat dilakukan adalah dengan mengolah limbah peternakan menjadi energi alternatif pengganti Bahan Bakar Minyak (BBM) yaitu biogas.

Prospek pengembangan teknologi biogas ini sangat besar terutama di daerah pedesaan dimana sebagian besarnya masyarakat bekerja dibidang peternakan dan pertanian (Febriyanita, 2015). Pengolahan limbah ternak sapi menjadi energi alternatif biogas yang ramah lingkungan merupakan cara yang sangat menguntungkan, karena mampu memanfaatkan alam tanpa merusaknya sehingga siklus ekologi tetap terjaga. Biomasa yang mengandung kadar air yang tinggi seperti kotoran hewan dan limbah pengolahan pangan cocok digunakan untuk bahan baku pembuatan biogas (Haryati, 2006). Biogas memiliki peluang yang besar dalam pengembangannya. Energi biogas dapat diperoleh dari air limbah rumah tangga, kotoran cair dari peternakan, sampah organik dari pasar, industri makanan dan sebagainya.

Biogas merupakan campuran gas metana $( \pm 60 \%)$, karbon dioksida $( \pm 38 \%)$, dan lainnya N2, O2, H2 \& H2S ( $\pm 2 \%$ ) sehingga dapat dibakar seperti layaknya gas elpiji sering dipakai untuk memasak dan penerangan (Sukarsono, 2011). Penguraian biomassa menjadi biogas juga menghasilkan kompos sehingga selain menyediakan sumber energi yang murah, usaha konversi ini juga menyediakan pupuk organik untuk mendukung kegiatan pertanian serta meningkatkan kebersihan lingkungan dan kesehatan keluarga di pedesaan (Said, 2008). Kapasitas terpasang pemanfaatan biogas adalah kurang dari satu persen dari potensi biogas yang ada (685 MW). Hal ini dapat di lihat pada tabel kesetaraan biogas dari limbah ternak sapi dengan energi lainnya.

Tabel 1. Kesetaraan Biogas Dari Limbah Ternak Sapi Dengan Energi Lainnya.

\begin{tabular}{cc}
\hline Volume & Kesetaraan \\
\hline & 0,46 kg LPG \\
$1 \mathrm{~m}^{3}$ biogas & 0,62 liter minyak tanah \\
& 3,5 kg kayu bakar \\
& 0,62 minyak solar \\
\hline
\end{tabular}

Sumber : (Mulyati., 2009)

Berdasarkan Tabel 1. menunjukkan bahwa dalam $1 \mathrm{~m}^{3}$ biogas dari limbah ternak sapi setara dengan 0,46 kg LPG, 0,6 liter minyak tanah, 3,5 kg kayu bakar, 0,62 minyak solar sehingga biogas lebih efisien dan mudah untuk dimanfaatkan sebagai energi alternatif rumah tangga seperti bahan bakar dan energi listrik. Hal ini, sangat mudah untuk dilakukan masyarakat dalam memanfaatkan limbah ternak yang mayoritas berada di daerah pedesaan. Biogas dapat dipergunakan dengan cara yang sama seperti gas-gas yang mudah terbakar lainnya. Pembakaran biogas dilakukan melalui proses pencampuran dengan sebagian oksigen (O2). Menurut Sukarsono, (2011) nilai kalori dari 1 meter kubik biogas sekitar 6.000 watt jam yang setara dengan setengah liter minyak diesel. Dengan demikian, biogas dapat mengurangi pengeluaran peternak dan mengurangi pencemaran lingkungan.

Selain biogas pengolahan limbah ternak sapi juga menghasilkan pupuk berupa pupuk padat dan pupuk cair. Pupuk dari limbah ternak sapi yang telah diambil biogasnya memiliki kadar pencemar BOD dan COD berkurang sampai 90\%, dengan kondisi ini pupuk dari limbah ternak sapi sudah tidak berbau (Putro, 2007). Permasalahan yang dihadapi peternak sapi mengenai tumpukan kotoran sapi yang menimbulkan bau tidak enak dan mengganggu kehidupan penduduk di sekitar kandang dapat diatasi. Populasi ternak sapi di berbagai Provinsi mengalami peningkatan setiap tahunnya terutama di Provinsi Lampung (Direktorat Jenderal Peternakan dan Kesehatan Hewan., 2016). Provinsi Lampung memiliki potensi besar dalam mengembangkan limbah ternak sapi menjadi biogas. Provinsi Lampung merupakan salah satu lumbung ternak sapi selain Jawa Tengah dan Jawa Timur (Direktorat Jenderal Peternakan dan Kesehatan Hewan., 2016). Populasi ternak sapi di Provinsi Lampung secara keseluruhan mengalami peningkatan selama tiga tahun terakhir (2013-2016) 
dengan nilai berturut-turut 88.532 ekor pada tahun 2013 dan 660.745 ekor pada tahun 2016 (Direktorat Jenderal Peternakan dan Kesehatan Hewan., 2016). Berdasarkan uraian diatas, maka tujuan penelitian adalah bagaimana strategi pengembangan biogas sebagai energi alternatif rumah tangga dengan memanfaatkan limbah ternak kotoran sapi.

\section{METODELOGI PENELITIAN \\ Lokasi dan Waktu Penelitian}

Penelitian ini dilaksanakan di Desa Sari Bakti Kecamatan Seputih Banyak, Kabupaten Lampung Tengah. Pemilihan lokasi dilakukan secara sengaja dengan pertimbangan penelitian yang dilakukan didasarkan pada kegiatan usaha pengembangan biogas dari limbah ternak sapi serta merupakan salah satu sentral produksi sapi di wilayah tersebut. Lokasi yang di pilih sangat cocok karena jumlah ternak sapi yang memadai dan limbah ternak sapi yang belum dimanfaatkan dengan baik. Penelitian ini dilaksanakan pada bulan Juli sampai dengan bulan November 2017.

\section{Metode Pengambilan Sampel}

Metode pengambilan sampel yang digunakan adalah nonprobability sampling dengan sampling jenuh (sensus). Teknik sampling jenuh (sensus) yaitu metode penarikan sampel bila semua anggota populasi dijadikan sebagai sampel, apabila jumlah populasi kecil, kurang dari 30 orang (Sugiyono, 2013). Dalam penelitian ini, sampel yang akan di ambil adalah seluruh peternak sapi pemakai biogas berjumlah 25 orang dan 4 orang ahli yang berkompeten dalam pengetahuan pengembangan biogas dari limbah ternak sapi.

\section{Metode, Jenis Data dan Teknik Pengumpulan Data}

Konsep manajemen strategis merupakan alat analisis data yang sudah didapatkan (soleh, 2009). Analisis data yang akan dilakukan yaitu analisis deskriptif kualitatif dan kuantitatif. Analisis deskriptif kualitatif digunakan untuk mendapatkan gambaran mengenai visi, misi dan mengambarkan lingkungan terkait dengan peluang, ancaman, kekuatan, kelemahan yang dimiliki oleh perusahaan serta perumusan strategi dengan menggunakan matriks swot. Sedangkan analisis kuantitatif menggunakan matriks ife (internal faktor evaluation), efe (eksternal faktor evaluation), dan ie (internal-eksternal).

Teknik pengumpulan data pada penelitian ini terdiri dari dua yaitu dengan pengumpulan data secara primer dan sekunder. Data primer merupakan data yang diperoleh dan dikumpulkan secara langsung peneliti dari hasil penelitian langsung untuk menjawab masalah atau tujuan penelitian yang dilakukan dengan cara observasi, wawancara, diskusi dan kuesioner. Sedangkan data sekunder merupakan data yang diperoleh dan kumpulkan dari pihak lain (pihak eksternal). Data sekunder diperoleh dari lembaga-lembaga atau instansi terkait seperti Badan Pusat Statistika, Dinas Energi dan Sumberdaya Mineral serta monografi desa Sari Bakti, Kecamatan Seputih Banyak. Jenis-jenis data yang digunakan dalam data sekunder ini adalah populasi ternak sapi, jumlah pengguna biogas dari limbah ternak sapi, dan data-data lain yang diperlukan untuk menunjang penelitian.

\section{Analisis SWOT}

Analisis SWOT digunakan untuk mengetahui Strengths, Weakness, Opportunity, dan Threats dalam pengembangan biogas dari limbah ternak sapi sebagai energi alternatif di Desa Sari Bakti Kecamatan Seputih Banyak Kabupaten Lampung Tengah. Selain itu, analisis SWOT biasanya digunakan untuk menganalisis suatu kondisi dimana akan dibuat sebuah rencana untuk melakukan suatu program kerja (Alma, 2013).

Matriks SWOT merupakan alat yang di pakai untuk menyusun strategi pengembangan. Matriks ini dapat menghasilkan 4 set alternatif strategi. Diagram matriks SWOT dapat di lihat pada Gambar 1. 


\begin{tabular}{lll}
\hline \multirow{2}{*}{ IFAS } & $\begin{array}{l}\text { Strength (S) } \\
\text { Tentukan 5-10 faktor-faktor } \\
\text { kekuataninternal }\end{array}$ & $\begin{array}{l}\text { Weaknesses (W) } \\
\text { Tentukan 5-10faktor-faktor } \\
\text { kelemahaninternal }\end{array}$ \\
\hline $\begin{array}{l}\text { Opportunities (O) } \\
\begin{array}{l}\text { Tentukan 5-10 faktor-faktor } \\
\text { peluang eksternal }\end{array}\end{array}$ & $\begin{array}{l}\text { Strategi S-O } \\
\text { Ciptakan strategi yang } \\
\text { menggunakan kekuatan } \\
\text { untuk memanfaatkan peluang }\end{array}$ & $\begin{array}{l}\text { Strategi W-O } \\
\text { Ciptakan strategi yang } \\
\text { meminimalkan kelemahan } \\
\text { untuk memanfaatkan peluang }\end{array}$ \\
\hline $\begin{array}{l}\text { Threaths (T) } \\
\text { Tentukan 5-10 faktor -faktor } \\
\text { ancaman eksternal }\end{array}$ & $\begin{array}{l}\text { Strategi S-T } \\
\text { Ciptakan strategi yang } \\
\text { menggunakan kekuatan } \\
\text { untuk mengatasi ancaman }\end{array}$ & $\begin{array}{l}\text { Strategi W-T } \\
\text { Ciptakan strategi yang } \\
\text { meminimalkan kelemahan } \\
\text { dan menghindari ancaman }\end{array}$ \\
\hline
\end{tabular}

Sumber: (Rangkuti, 2013)

\section{HASIL DAN PEMBAHASAN}

\section{Keragaan Biogas Limbah Ternak Sapi Sebagai Energi Alternatif Rumah Tangga} Limbah ternak sebagai bahan baku biogas

Saat ini, masalah lingkungan hidup bukan hanya ditimbulkan oleh limbah dari pabrik kimia, tekstil dan usaha manufaktur lainnya. Industri peternakan juga mulai memberikan andil yang signifikan terhadap permasalahan lingkungan hidup. Usaha peternakan yang selama ini dipandang sebagai usaha yang akrab dengan lingkungan mulai dituding sebagai usaha yang ikut mencemari lingkungan hidup (Maksudi, 1993). Usaha peternakan sapi di Indonesia sampai saat ini masih mementingkan produktivitas ternak dan belum mempertimbangkan aspek lingkungan atau dampak kegiatan terhadap lingkungan (Sarwanto, 2004). Sedangkan (Melse \& Timmerman, 2009), mengatakan bahwa peternakan berkelanjutan tidak hanya memperhatikan kelangsungan hidup ternak dan produksinya namun juga penanganan limbah yang dapat mencemari lingkungan khususnya di daerah dengan kepadatan ternak yang tinggi. Akibat pengelolaan ternak yang tidak memperhatikan lingkungan, banyak usaha peternakan yang tidak berhasil dikarenakan timbulnya kerugian yang disebabkan oleh limbah yang tidak dikelola dengan benar (Sudiarto, 2008).

\section{Hasil utama ternak.}

Secara garis besar, ternak yang dipelihara manusia meliputi sapi, kerbau, domba, kambing, dan ayam. Hasil utama usaha peternakan berupa daging. Daging yang sehat dapat dilihat dari warna daging. Warna daging dipengaruhi oleh beberapa hal yaitu pakan, jenis, negara, usia, jenis kelamin, tingkat stress, pH dan oksigen (Purbowati et al., 2005).

\section{Hasil sampingan ternak}

Suatu usaha peternakan pasti menghasilkan limbah. Limbah ternak merupakan sisa buangan dari suatu kegiatan usaha peternakan seperti usaha pemeliharaan ternak, rumah pemotongan hewan dan pengolahan produk ternak. Limbah peternakan yang dihasilkan tidak lagi menjadi beban biaya usaha akan tetapi menjadi hasil ikutan yang memiliki nilai ekonomi tinggi dan bila mungkin setara dengan nilai ekonomi produk utama (daging) (Sudiarto, 2008). Dengan begitu, usaha peternakan ke depan harus dapat dibangun secara berkesinambungan sehingga dapat memberikan kontribusi pendapatan yang besar dan berkelanjutan (Sudiarto, 2008). Jarmani, (2008) mengatakan penerapan teknologi budidaya ternak yang ramah lingkungan dapat dilakukan melalui pemanfaatan limbah pertanian yang diperkaya nutrisinya serta pemanfaatan kotoran ternak menjadi pupuk organik dan biogas dapat meningkatkan produktivitas ternak, peternak dan perbaikan lingkungan.

\section{Biogas dari hasil pemanfaatan kotoran ternak}


Mendirikan suatu peternakan harus dimulai dengan perencanaan yang matang, tidak hanya terfokus pada aspek produksi utama, tetapi harus memerhatikan faktor lain. Suatu peternakan yang layak sebaiknya mempunyai mekanisme kerja yang baik dalam mengolah limbah yang dihasilkan. Apalagi jika suatu peternakan itu memiliki skala usaha yang besar dan intensif. Kegiatan peternakan sapi dapat memberikan dampak positif terhadap pembangunan, yaitu peningkatan pendapatan peternak, perluasan kesempatan kerja, peningkatan ketersediaan pangan dan penghematan devisa (Cyrilla, 2016). Namun tanpa dilakukan pengolahan limbah yang tepat, kegiatan ini menimbulkan permasalahan lingkungan. Usaha untuk mengurangi bahkan mengeliminasi dampak negatif dari kegiatan usaha peternakan sapi ini terhadap lingkungan tergantung pada beberapa faktor seperti kebijakan pemerintah dan ketersediaan teknologi pengolahan limbah (Sri \& Saleh, 2009). Energi biogas adalah salah satu dari banyak macam sumber energi terbarukan, karena energi biogas dapat diperoleh dari air buangan rumah tangga, kotoran cair dari peternakan ayam, sapi, babi, sampah organik dari pasar, industri makanan dan limbah buangan lainnya (Elizabeth \& Rusdiana, 2008). Peternakan ayam di Indonesia saat ini berkembang dengan cukup pesat (Tantalo, 2010), sehingga peluang kotoran untuk dimanfaatkan sangat terbuka tapi kotoran peternakan sapi lebih dimanfaatkan masyarakat untuk biogas. Produksi biogas memungkinkan pertanian berkelanjutan dengan sistem proses terbarukan dan ramah lingkungan (Sri Wahyuni \& Saleh, 2009). Pada satu ekor sapi setiap harinya menghasilkan kotoran berkisar $8-10 \mathrm{~kg}$ per hari atau 2,6 -3,6 ton per tahun atau setara dengan 1,52 ton pupuk organik sehingga akan mengurangi penggunaan pupuk anorganik dan mempercepat proses perbaikan lahan (Huda \& Wikanta, 2018). Potensi jumlah kotoran sapi dapat dilihat dari populasi sapi. Populasi sapi potong di Indonesia diperkirakan 10,8 juta ekor dan sapi perah 350.000 - 400.000 ekor dan apabila satu ekor sapi rata-rata setiap hari menghasilkan 7 kilogram kotoran kering maka kotoran kotoran sapi kering yang dihasilkan di Indonesia sebesar 78,4 juta kilogram kering per hari (Budiyanto, 2011). Keadaan potensial inilah yang menjadi alasan perlu adanya penanganan yang benar pada kotoran ternak. Di samping itu, dari proses produksi biogas akan dihasilkan sisa kotoran ternak yang dapat langsung dipergunakan sebagai pupuk organik pada tanaman/budidaya pertanian. Limbah biogas, yaitu kotoran ternak yang telah hilang gasnya (slurry) merupakan pupuk organik yang sangat kaya akan unsur-unsur yang dibutuhkan oleh tanaman. Bahkan, unsur-unsur tertentu seperti protein, selulose, lignin dan lain-lain tidak dapat digantikan oleh pupuk kimia. Pupuk organik dari biogas telah dicobakan pada tanaman jagung, bawang merah dan padi.

\section{Potensi Biogas bagi Kehidupan Masyarakat}

Kotoran ternak berupa feses dan urine telah dimanfaatkan manusia sejak berabad-abad yang lalu. Adanya dekomposisi bahan organik secara anaerobik (tertutup dari udara bebas) untuk menghasilkan suatu gas yang sebagian besar berupa metana (yang memiliki sifat mudah terbakar) dan karbondioksida. Gas yang terbentuk disebut gas rawa atau biogas. Proses dekomposisi anaerobik dibantu oleh sejumlah mikroorganisme, terutama bakteri metana. Suhu yang baik untuk proses fermentasi adalah $30-55^{\circ} \mathrm{C}$ (Fitriyanto et al., 2019). Pada suhu tersebut mikroorganisme dapat bekerja secara optimal merombak bahan-bahan organik menjadi gas metana. Pembuatan biogas bukan merupakan teknologi baru. Berbagai negara telah mengaplikasikan teknologi ini sejak puluhan tahun yang lalu seperti petani di Inggris, Rusia dan Amerika Serikat (Wahyuni, 2008). Potensi limbah peternakan sebagai salah satu bahan baku pembuatan biogas dapat ditemukan di sentra-sentra peternakan, terutama peternakan dengan skala besar yang menghasilkan limbah dalam jumlah besar dan rutin (Haryati, 2006). Di Indonesia cukup banyak kawasan peternakan sapi yang limbah kotoran sapinya belum dimnfaatkan sebagai pembangkit listrik secara maksimum dengan limbah peternakan yang didapatkan dari feases, urine beserta sisa pakan ternak sapi dapat dimanfaatkan untuk menghasilkan biogas (Priyadi, 2016).

\section{Perkembangan Biogas}

Hal 49 Volume 19, Nomor 1, 2019 
Perkembangan teknologi biogas di Indonesia sudah dikenal sejak tahun 1970-an. Teknik pengolahan limbah ternak dengan menggunakan instalasi biogas dikembangkan di pedesaan, tetapi pada saat ini teknologi biogas sudah mulai dipergunakan di perkotaan. Pada tahun 1981-an, pengembangan teknologi pengolahan limbah dengan instalasi biogas di Indonesia sudah dikembangkan melalui dukungan bantuan dana dari Food and Agriculture Organization (FAO) seperti instalasi biogas di beberapa provinsi. Pada tahun 2000-an telah dikembangkan reaktor biogas skala rumah tangga dengan konstruksi yang masih sederhana, dengan bahan yang terbuat dari plastik yang siap pasang dengan harga yang relatif terjangkau (Febriyanita, 2015)

\section{Strategi Pengembangan Biogas dari Limbah Ternak Sapi sebagai Energi Alternatif Rumah Tangga}

Kekuatan dan kelemahan digolongkan ke dalam faktor internal karena faktor-faktor tersebut merupakan peubah-peubah yang dapat dikendalikan oleh peternak. Peluang dan ancaman termasuk dalam faktor eksternal yang terdiri dari peubah-peubah di luar kendali peternak. Berdasarkan informasi yang di peroleh dari hasil wawancara dan pengamatan langsung di lokasi biogas, dapat diidentifikasikan bahwa faktor-faktor strategis internal yaitu kekuatan dan kelemahan pengembangan biogas sedangkan faktor-faktor strategis eksternal yaitu peluang dan ancaman yang di hadapi dalam pengembangan biogas. Faktor-faktor strategis tersebut kemudian di analisis dengan matriks analisis SWOT dan dihasilkan empat strategi yaitu strategi SO, strategi WO, strategi ST, dan strategi WT (Rangkuti, 2013).

Analisis Faktor Internal dan Eksternal Menggunakan Matriks IFAS dan EFAS. Berdasarkan identifikasi terhadap faktor-faktor Internal Factor Analysis Strategic (IFAS) dan Eksternal Factor Analysis Strategic (EFAS) di peroleh kekuatan kelemahan, peluang dan ancaman yang di miliki biogas limbah ternak sapi di Desa Sari Bakti Kecamatan Seputih Banyak Kabupaten Lampung Tengah Tabel 2 dan 3.

Tabel 2. Matriks Internal Factor Analysis Strategic (IFAS)

\begin{tabular}{|c|c|c|c|}
\hline Faktor-faktor Strategi Internal & Bobot & Rating & Skor Pembobotan \\
\hline \multicolumn{4}{|l|}{ Kekuatan } \\
\hline 1. Adanya kelompok peternak sapi & 0,19 & 2,40 & 0,46 \\
\hline $\begin{array}{l}\text { 2. Terdapat jumlah ternak yang memadai sebagai } \\
\text { penghasil biogas }\end{array}$ & 0,14 & 3,56 & 0,50 \\
\hline $\begin{array}{l}\text { 3. Biogas dapat mengurangi biaya bahan bakar } \\
\text { yang berupa LPG dan menghemat listrik }\end{array}$ & 0,10 & 3,76 & 0,38 \\
\hline $\begin{array}{l}\text { 4. Biogas sudah di manfaatkan sebagai bahan } \\
\text { bakar yang murah dan terjangkau }\end{array}$ & 0,10 & 3,96 & 0,40 \\
\hline 5. Mengurangi pencemaran lingkungan & 0,04 & 3,60 & 0,14 \\
\hline Sub total & $\mathbf{0 , 5 7}$ & & $\mathbf{1 , 8 7}$ \\
\hline \multicolumn{4}{|l|}{ Kelemahan } \\
\hline 1. Biogas belum di kenal di lingkungan masyarakat & 0,14 & 3,68 & 0,52 \\
\hline 2. Pendidikan peternak sapi relatif masih rendah & 0,09 & 3,44 & 0,31 \\
\hline 3. Rumah peternak sapi yang jauh dari kandang & 0,07 & 3,68 & 0,26 \\
\hline $\begin{array}{l}\text { 4. Biogas tidak dapat di kemas dalam bentuk cair } \\
\text { dalam tabung }\end{array}$ & 0,06 & 3,84 & 0,23 \\
\hline $\begin{array}{l}\text { 5. Kurang kesadaran peternak sapi dalam menjaga } \\
\text { lingkungan }\end{array}$ & 0,07 & 2,24 & 0,16 \\
\hline Sub total & $\mathbf{0 , 4 3}$ & & 1,47 \\
\hline Total & 1,00 & & 3,34 \\
\hline Selisih skor & & & $\mathbf{0 , 4 0}$ \\
\hline
\end{tabular}

Sumber : Data primer di olah, 2017 
Tabel 2 menunjukkan bahwa hasil dari faktor strategi internal yang merupakan kekuatan terbesar dan paling berpengaruh terhadap strategi pengembangan biogas di Desa Sari Bakti Kecamatan Seputih Banyak Kabupaten Lampung Tengah adalah terdapat jumlah ternak yang memadai sebagai penghasil biogas yang memiliki skor pembobotan sebesar 0,50 . Hal ini menunjukkan bahwa apabila terdapat ternak yang memadai maka akan mempermudah peternak dalam mengembangkan biogas karena tersedianya bahan baku yang banyak untuk dijadikan biogas (Renosori, 2012). Energi biogas dapat dimanfaatkan sebagai pengganti bahan bakar yang dipergunakan untuk memasak. Selain itu, biogas dapat digunakan sebagai pembangkit energi listrik. Di samping itu, dari proses produksi biogas akan dihasilkan sisa-sisa kotoran yang dapat langsung dipergunakan sebagai pupuk organik pada tanaman pertanian (Mulyati., 2009). Sedangkan faktor strategi internal yang merupakan kelemahan terhadap strategi pengembangan biogas di Desa Sari Bakti Kecamatan Seputih Banyak adalah biogas belum di kenal di lingkungan masyarakat dengan skor pembobotan 0,52. Hal ini menunjukkan bahwa peternak belum mengenal biogas baik dari segi manfaatnya maupun cara penggunaanya (Widyastuti \& Purwanto, 2013). Biogas yang dihasilkan dari limbah ternak sapi, walaupun masih dalam skala kecil, namun telah dapat memberikan manfaat yang cukup berarti bagi peternak untuk memenuhi kebutuhan terutama untuk kebutuhan rumah tangga peternak sehari-hari seperti bahan bakar memasak. Hal ini dapat dilihat dari produksi biogas yang dihasilkan telah dapat dimanfaatkan peternak. Menurut Musanif et al., (2006). bahwa sumber energi yang berasal dari biogas tersebut dapat dimanfaatkan sebagai sumber energi rumah tangga seperti LPG untuk memasak, penerangan dan menggerakkan generator sehingga dapat dijadikan sumber energi alternatif yang ramah lingkungan dan terbarukan, hal ini sejalan dengan daerah penelitian di Desa Sari Bakti Kecamatan Seputih Banyak.

Berdasarkan perhitungan matriks IFAS untuk kekuatan mendapatkan skor 1,87 dan kelemahan mendapatkan skor 1,47 . Sehingga di peroleh total nilai pada posisi internal rata-rata yang di lihat dari bobot yaitu sebesar 3,34. Hal ini bahwa skor kekuatan pada pengembangan biogas di Desa Sari Bakti Kecamatan Seputih Banyak lebih besar dari pada kelemahannya. Oleh karena itu, harus memanfaatkan kekuatan yang ada untuk mengatasi kelemahan yang ada pada pengembangan biogas (Sofyan, 2008). Hal ini menunjukkan bahwa pengembangan biogas dari limbah kotoran ternak sapi telah mampu merespon faktor internal dengan memanfaatkan kekuatan yang di miliki sehingga dapat mengatasi kelemahan yang ada.

Tabel 3. Matriks Eksternal Factor Analysis Strategic (EFAS)

\begin{tabular}{|c|c|c|c|}
\hline Faktor-faktor Strategi Eksternal & Bobot & Rating & Skor Pembobotan \\
\hline \multicolumn{4}{|l|}{ Peluang } \\
\hline 1. Tersedianya berbagai bantuan dari pemerintah & 0,19 & 3,64 & 0,69 \\
\hline $\begin{array}{l}\text { 2. Mendorong program pemerintah dalam mengurangi } \\
\text { pencemaran lingkungan }\end{array}$ & 0,15 & 3,84 & 0,58 \\
\hline 3. Tersedianya teknolog yang efektif dan efisien & 0,06 & 3,96 & 0,24 \\
\hline $\begin{array}{l}\text { 4. Meningkatkan pendapatan kesejahteraan } \\
\text { masyarakat }\end{array}$ & 0,10 & 3,48 & 0,35 \\
\hline 5. Meningkatkan kemampuan daya beli masyarakat. & 0,05 & 3,92 & 0,20 \\
\hline Sub total & $\mathbf{0 , 5 5}$ & & 2,05 \\
\hline \multicolumn{4}{|l|}{ Ancaman } \\
\hline 1. Terdapat penyakit pada ternak sapi & 0,17 & 1,48 & 0,25 \\
\hline $\begin{array}{l}\text { 2. Kebocoran reaktor dapat menyebabkan terjadinya } \\
\text { kebakaran }\end{array}$ & 0,07 & 1,88 & 0,13 \\
\hline $\begin{array}{l}\text { 3. Pola hidup dan budaya tidak hemat energi pada } \\
\text { masyarakat }\end{array}$ & 0,05 & 2,44 & 0,12 \\
\hline $\begin{array}{l}\text { 4. Harga elpiji subsidi relatif murah dan mudah di } \\
\text { dapatkan }\end{array}$ & 0,06 & 3,16 & 0,19 \\
\hline 5. Menurunnya populasi ternak sapi & 0,10 & 2,48 & 0,25 \\
\hline Sub total & 0,45 & & 0,94 \\
\hline
\end{tabular}




\begin{tabular}{lcc}
\hline Total & 1,00 & 2,99 \\
\hline Selisih skor & & 1,11 \\
\hline Sumber : Data pring
\end{tabular}

Sumber : Data primer di olah, 2017

Berdasarkan tabel 3 menunjukkan bahwa hasil dari faktor strategi eksternal yang merupakan peluang terbesar dan paling berpengaruh terhadap strategi pengembangan biogas di Desa Sari Bakti Kecamatan Seputih Banyak yaitu tersedianya berbagai bantuan dari pemerintah dengan nilai skor pembobotan sebesar 0,69. Hal ini menunjukkan bahwa tersedianya bantuan dari pemerintah merupakan fasilitas yang sangat mendukung pengembangan biogas seperti pemasangan instalasi biogas. Dengan $90 \%$ dari kotoran ternak sebenarnya sudah digunakan menjadi biogas kompor dan sisanya dibuang, hanya tersisa $10 \%$ yang dimanfaatkan menjadi tenaga listrik. Sangat potensial jika pemanfaatan keseluruhan biogas tersebut untuk memenuhi kebutuhan listrik disekitarnya (Yusuf \& Efrita, 2014). Sedangkan faktor strategi eksternal yang merupakan ancaman terbesar dan paling berpengaruh terhadap pengembangan biogas di Desa Sari Bakti Kecamatan Seputih Banyak adalah adanya penyakit pada sapi dengan nilai skor pembobotan sebesar 0,25. Hal ini menunjukkan bahwa penyakit sapi merupakan ancaman terbesar dalam pengembangan biogas, dikarenakan apabila sapi peternak terkena serangan penyakit maka jumlah limbah ternak yang di keluarkan oleh sapi tersebut akan berkurang sehingga dapat berpengaruh terhadap penggunaan biogas (Teguh, 2007). Keberhasilan pengelolaan biogas bisa dilihat dari berbagai faktor, salah satunya adalah faktor lingkungan dimana bisa memunculkan dampak positif berupa pengurangan limbah pertanian. Faktor keberhasilan lainnya bisa dilihat dari energi biogas mudah dikelola oleh rumah tangga. Dalam aspek manajemen proses pemeliharaan dan perawatan instalasi biogas masyarakat pengguna masih menemui kendala (Kasdin, 2015).

Berdasarkan perhitungan matriks EFAS untuk peluang mendapatkan skor 2,05 dan ancaman mendapatkan skor 0,94 . Sehingga di peroleh total nilai eksternal rata-rata yaitu sebesar 2,99. Hal ini menunjukkan bahwa skor peluang yang di miliki peternak di Desa Sari Bakti Kecamatan Seputih Banyak lebih besar dari ancamannya, sehingga dapat memanfaatkan peluang untuk mengantisipasi kemungkinan ancaman yang di hadapi (Renosori, 2012). Hal ini menunjukkan bahwa pengembangan biogas dari limbah ternak sapi telah mampu merespon faktor eksternal dengan memanfaatkan peluang yang ada sehingga dapat mengatasi ancaman eksternal.

Analisis SWOT digunakan untuk mengidentifikasi berbagai faktor untuk merumuskan strategi. Berdasarkan data faktor internal dan faktor eksternal didapatkan skor pembobotan sebagai berikut : faktor kekuatan $=1,87$, faktor kelemahan $=1,47$, faktor peluang $=2,05$, dan faktor ancaman $=0,94$. Analisis SWOT yang dilakukan sebelumnya dapat digunakan sebagai dasar dalam penentuan strategi pengembangan biogas di Desa Sari Bakti Kecamatan Seputih Banyak Kabupaten Lampung Tengah kedepan. Analisis SWOT dibangun berdasarkan hasil analisis faktor-faktor strategis internal maupun eksternal yang terdiri dari berbagai faktor kekuatan, kelemahan, peluang dan ancaman. Hasil analisis pada gambar 1 grafik analisis SWOT di peroleh titik koordinat $(0,40 ; 1,11)$ yang mana koordinat ini masuk pada kuadran I, yakni posisi ini menandakan sebuah usaha atau organisasi yang kuat dan berpeluang (Pearce, J. and Robinson, 1998). Rekomendasi strategi yang diberikan adalah " Progresif” artinya usaha dalam kondisi prima dan mantap sehingga sangat mungkin untuk terus melakukan ekspansi, meningkatkan pertumbuhan dan meraih kemajuan secara maksimal. 


$$
\begin{gathered}
\frac{1,87-1,47}{2} ; \frac{2,05-0,94}{2} \\
0,40 ; 1,11
\end{gathered}
$$

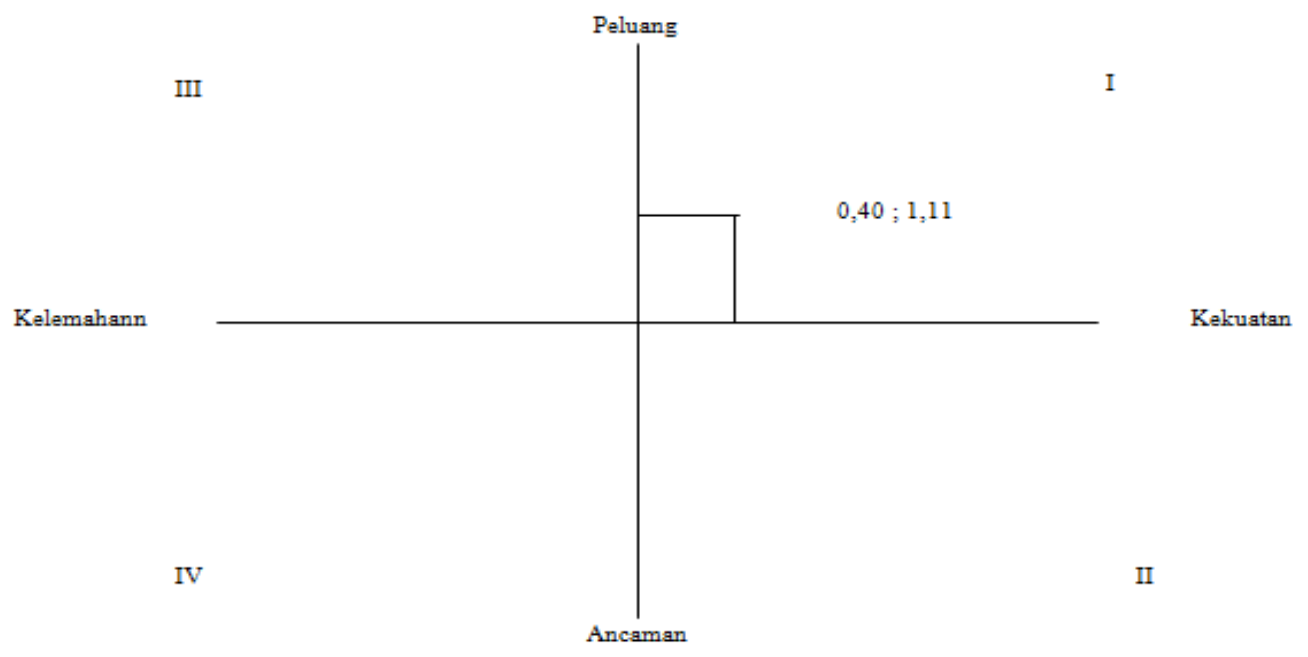

Gambar 1. Grafik Analisis SWOT Pengembangan Biogas dari Limbah Ternak Sapi

Perioritas strategi pengembangan dengan Analisis SWOT dengan hasil penggabungan perhitungan pembobotan rating IFAS dan EFAS dapat dilihat pada Tabel 4.

Tabel 4. Pembobotan Rating IFAS dan EFAS

\begin{tabular}{ccc}
\hline & $\mathbf{O}=\mathbf{2 , 0 5}$ & $\mathbf{T}=\mathbf{0 , 9 4}$ \\
\hline $\mathbf{S}=\mathbf{1 , 8 7}$ & $\mathrm{SO}=3,89$ & $\mathrm{ST}=2,81$ \\
$\mathbf{W}=\mathbf{1 , 4 7}$ & $\mathrm{WO}=3,52$ & $\mathrm{WT}=2,41$ \\
\hline
\end{tabular}

Berdasarkan tabel 4 menunjukkan bahwa hasil pembobotan rating hasil SWOT, maka dapat disusun prioritas strategi berdasarkan kombinasi strategi yang paling tinggi sampai dengan paling rendah, dapat dilihat pada Tabel 5.

Tabel 5.Tingkat Prioritas Strategi SWOT

\begin{tabular}{ccc}
\hline Prioritas & Strategi & Bobot Nilai \\
\hline I & Strengh-Opportunity $(S O)$ & 3,89 \\
II & Strengh-Threat $(S T)$ & 2,81 \\
III & Weakness-Opportunity $(W O)$ & 3,52 \\
IV & Weakness-Threat $(W T)$ & 2,41 \\
\hline
\end{tabular}

Berdasarkan tabel 5 menunjukkan bahwa hasil interaksi IFAS dan EFAS yang menghasikan alternatif strategi yang mendapatkan bobot tertinggi adalah Strengh-Opportunity (SO) dengan skor 3,89 diterjemahkan sebagai strategi yang menggunakan kekuatan untuk memanfaatkan peluang. Strategi untuk pengembangan biogas memiliki bobot kekuatan yang lebih besar dari pada kelemahan, sedangkan bobot peluang lebih besar daripada ancaman dalam pengembangan biogas dari limbah ternak sapi di Desa Sari Bakti Kecamatan Seputih Banyak Kabupaten Lampung Tengah.

Tujuan dari tahap analisis terhadap faktor-faktor strategi dengan matrik SWOT adalah untuk menghasilkan altenatif strategi yang layak. Berdasarkan matrik SWOT dihasilkan strategi Strengh- 
Opportunity (SO), Strengh-Threat (ST), Weakness-Opportunity (WO), dan Weakness-Threat (WT). Hasil analisis terhadap empat strategi yang disarankan dapat dilihat pada Tabel 6.

Berdasarkan hasil pembobotan nilai tertinggi adalah strategi Strengh-Opportunity $(\mathrm{SO})$ terletak pada kuadran I. Pada kuadran ini merupakan situasi yang sangat kuat dan berpeluang. Tingginya strategi nilai prioritas SO bukan berati strategi lain yang memiliki nilai rendah tidak bermanfaat dan tidak perlu diterapkan. Akan tetapi, apabila ingin mendapatkan hasil yang maksimal perlu ditunjang dengan strategi ST, WO dan WT. Alternatif strategi yang dapat diterapkan yaitu dengan memanfaatkan keberadaan kelompok ternak sapi untuk memperoleh bantuan dari pemerintah dalam rangka mengurangi pencemaran lingkungan dan meningkatkan kesejahteraan masyarakat, selain itu perlu meningkatkan sosialisasi biogas sebagai energi alternatif rumah tangga agar di kenal masyarakat secara umum sehingga dapat mengatasi harga elpiji yang semakin meningkat dengan cara meningkatkan peranan kelompok peternak dalam menginovasi teknologi energi alternatif.

Tabel 6. Matriks SWOT Pengembangan Biogas dari Limbah Ternak Sapi di Desa Sari Bakti Kecamatan Seputih Banyak

\begin{tabular}{|c|c|c|}
\hline $\begin{array}{l}\text { Eksternal Factor } \\
\text { Analysis } \\
\text { Strategic (EFAS) }\end{array}$ & $\begin{array}{l}\text { 1. Terdapat jumlah ternak yang } \\
\text { memadai sebagai penghasil } \\
\text { biogas } \\
\text { 2. Adanya kelompok peternak } \\
\text { sapi } \\
\text { 3. Biogas sudah di manfaatkan } \\
\text { sebagai bahan bakar yang } \\
\text { murah dan terjangkau }\end{array}$ & $\begin{array}{l}\text { 1. Biogas belum di kenal di } \\
\text { lingkungan masyarakat } \\
\text { 2. Pendidikan peternak sapi } \\
\text { relatif rendah } \\
\text { 3. Rumah peternak sapi jauh dari } \\
\text { kandang }\end{array}$ \\
\hline Peluang $(\mathrm{O})$ & Strategi $\mathrm{S}-\mathrm{O}$ & Strategi $\mathrm{W}-\mathrm{O}$ \\
\hline $\begin{array}{l}\text { 1. Tersedianya berbagai bantuan } \\
\text { dari pemerintah } \\
\text { 2. Mendorong program } \\
\text { pemerintah dalam mengurangi } \\
\text { pencemaran lingkungan } \\
\text { 3. Meningkatkan pendapatan } \\
\text { kesejahteraan masyarakat }\end{array}$ & $\begin{array}{l}\text { 1. Memanfaatkan kelompok } \\
\text { ternak untuk memperoleh } \\
\text { bantuan dari pemerintahdalam } \\
\text { rangka mengurangi } \\
\text { pencemaran dan } \\
\text { meningkatkan pendapatan } \\
\text { masyarakat. ( } \mathrm{S} 2, \mathrm{O} 1 . \mathrm{O} 2 . \mathrm{O} 3 \text { ) } \\
\text { 2. } \text { Memanfaatkan ketersediaan } \\
\text { jumlah ternak dalam upaya } \\
\text { mengurangi pencemaran } \\
(\mathrm{S} 1, \mathrm{O} 2)\end{array}$ & $\begin{array}{l}\text { 1. Meningkatkan sosialisasi } \\
\text { biogas agar di kenal } \\
\text { masyarakat sehingga dapat } \\
\text { mendukung program } \\
\text { pemerintah dalam mengurangi } \\
\text { pencemaran dan } \\
\text { meningkatkan pendapatan } \\
\text { masyarakat (W1,O2,O3) } \\
\text { 2. Meningkatkan pengetahuan } \\
\text { peternak sehingga dapat } \\
\text { mengoptimalkan bantuan dari } \\
\text { pemerintah (W2,O1) }\end{array}$ \\
\hline Ancaman $(\mathrm{T})$ & Strategi $\mathrm{S}-\mathrm{T}$ & Strategi $\mathrm{W}-\mathrm{T}$ \\
\hline $\begin{array}{l}\text { 1. Terdapat penyakit pada ternak } \\
\text { sapi } \\
\text { 2. Menurunnya populasi ternak } \\
\text { 3. Harga elpiji subsidi relatif } \\
\text { murah dan mudah di dapatkan }\end{array}$ & $\begin{array}{l}\text { 1. Memanfaatkan kelompok } \\
\text { peternak untuk mengatasi } \\
\text { penurunan populasi dan } \\
\text { penyakit sapi (S2,T1,T2) } \\
\text { 2. Mengoptimalkan pemanfaatan } \\
\text { biogas sehingga menjadi } \\
\text { bahan bakar yang murah } \\
\text { dengan meminimalkan } \\
\text { penurunan populasi ternak ( } \\
\mathrm{S} 3, \mathrm{~T} 2)\end{array}$ & $\begin{array}{l}\text { 1. Meningkatkan pengenalan } \\
\text { biogas kepada masyarakat } \\
\text { sehingga dapat mengatasi } \\
\text { harga elpiji yang semakin } \\
\text { meningkat (W1,T3)) } \\
\text { 2. Meningkatkan pengetahuan } \\
\text { peternak sehingga dapat } \\
\text { mencegah menurunnya } \\
\text { populasi dan penyakit ternak } \\
\text { sapi (W2,T1,T2) }\end{array}$ \\
\hline
\end{tabular}

Sumber : Data di olah, 2017 


\section{KESIMPULAN}

Strategi yang dapat dilakukan dalam pengembangan biogas dari limbah ternak sapi di Desa Sari Bakti Kecamatan Seputih Banyak berada pada koordinat $(0,40 ; 1,11)$ yaitu terletak pada kuadran I posisi ini menandakan sebuah usaha yang kuat dan memiliki berpeluang untuk dikembangkan. Alternatif strategi pengembangan biogas yang dapat diterapkan yaitu (1) memanfaatkan kelompok ternak untuk memperoleh bantuan dari pemerintahdalam rangka mengurangi pencemaran dan meningkatkan pendapatan masyarakat, (2) memanfaatkan ketersediaan jumlah ternak dalam upaya mengurangi pencemaran, (3) meningkatkan sosialisasi biogas agar di kenal masyarakat sehingga dapat mendukung program pemerintah dalam mengurangi pencemaran dan meningkatkan pendapatan masyarakat, (4) meningkatkan pengetahuan peternak sehingga dapat mengoptimalkan bantuan dari pemerintah, (5) memanfaatkan kelompok peternak untuk mengatasi penurunan populasi dan penyakit sapi, (6) mengoptimalkan pemanfaatan biogas sehingga menjadi bahan bakar yang murah dengan meminimalkan penurunan populasi ternak, (7) meningkatkan pengenalan biogas kepada masyarakat sehingga dapat mengatasi harga elpiji yang semakin meningkat, (8) meningkatkan pengetahuan peternak sehingga dapat mencegah menurunnya populasi dan penyakit ternak sapi.

\section{SARAN}

Peternak diharuskan lebih menjaga ternaknya agar biogas dapat tersedia secara kontinyu dalam pemenuhan energi alternatif rumah tangga dan untuk pemerintah diperlukan bantuan atau subsidi agar biogas tetap berjalan dan berkembang dalam memenuhi kebutuhan masyarakat yang terus meningkat terhadap energi alternatif dari limbah ternak sapi.

\section{DAFTAR PUSTAKA}

Alma, B. (2013). Manajemen Pemasaran Dan Pemasaran Jasa. In Edisi Kelima cetakan Revisi, Bandung: Alfabeta. https://doi.org/10.1016/j.knosys.2008.03.040

Budiyanto, M. A. K. (2011). TIPOLOGI PENDAYAGUNAAN KOTORAN SAPI DALAM UPAYA MENDUKUNG PERTANIAN ORGANIK DI DESA SUMBERSARI KECAMATAN PONCOKUSUMO KABUPATEN MALANG. Jurnal Gamma, 7, 42-49. Retrieved from http://ejournal.umm.ac.id/index.php/gamma/article/view/1420

Cyrilla, L., S. and H. M. (2016). Dampak Eksternalitas Peternakan Kambing Perah terhadap Kehidupan Masyarakat Sekitar. Jurnal Ilmu Produksi Dan Teknologi Hasil Peternakan, 4 (3), 334-339.

Direktorat Jenderal Peternakan dan Kesehatan Hewan. (2016). Populasi Ternak Menurut Provinsi. Jakarta: Direktorat Jenderal Peternakan dan Kesehatan Hewan.

Elizabeth, R., \& Rusdiana, S. (2008). Efektivitas Pemanfaatan Biogas Sebagai Sumber Bahan Bakar Dalam Mengatasi Biaya Ekonomi Rumah Tangga Di Perdesaan. Pusat Studi Ekonomi, 220-234.

Febriyanita, W. (2015). Pengembangan Biogas Dalam Rangka Pemanfatan Energi Terbarukan di Desa Jetak Kecamatan Getasan Kabupaten Semarang. Universitas Negeri Semarang.

Fitriyanto, N. A., Triatmojo, S., Pertiwiningrum, A., Erwanto, Y., Abidin, M. Z., Baliarti, E., \& Suranindyah, Y. Y. (2019). Penyuluhan dan Pendampingan Pengolahan Limbah Peternakan Sapi Potong di Kelompok Tani Ternak Sido Mulyo Dusun Pulosari, Desa Jumoyo, Kecamatan Salam, Kabupaten Magelang. Jurnal Pengabdian Kepada Masyarakat (Indonesian Journal of Community Engagement), 1(1), 79-95. https://doi.org/10.22146/jpkm.16955

Haryati, T. (2006). Biogas : limbah peternakan yang menjadi sumber energi alternatif. Wartazoa, 16(3), 160169. 
Huda, S., \& Wikanta, W. (2018). Pemanfaatan Limbah Kotoran Sapi Menjadi Pupuk Organik Sebagai Upaya Mendukung Usaha Peternakan Sapi Potong di Kelompok Tani Ternak Mandiri Jaya Desa Moropelang Kecamatan Babat Kabupaten Lamongan. AKSIOLOGIYA : Jurnal Pengabdian Kepada Masyarakat, 1(1), 26. https://doi.org/10.30651/aks.v1i1.303

Jarmani, S. N. (2008). Penampilan Budidaya Ternak Ruminansia di Pedesaan Melalui Teknologi Ramah Lingkungan. Prosiding Seminar Nasional Teknologi Peternakan Dan Veteriner, 346-353. Bogor: Balai Penelitian Ternak.

Kasdin, K. (2015). Evaluasi Pengelolaan Limbah Peternakan Menjadi Biogas di Kelurahan Ngadirgo, Kecamatan Mijen, Kota Semarang. Prosiding Seminar Nasional Innovation in Environmental Management, 1-4. Semarang: Diponegoro University dan Queensland University.

Mulyati, M. (2009). Desain Alat Biogas Dari Kotoran Sapi Skala Rumah Tangga. Jurnal Teknik Industri, 9 (1), 1-16.

Maksudi, A. . (1993). Dampak Lingkungan dari Usaha Peternakan Sapi Perah Rakyat (Kasus di Kelurahan Kebon Pedes. Kotamadya Bogor). Institut Pertanian Bogor.

Melse, R. W., \& Timmerman, M. (2009). Sustainable intensive livestock production demands manure and exhaust air treatment technologies. Bioresource Technology, 100(22), 5506-5511. https://doi.org/10.1016/j.biortech.2009.03.003

Mulyana, E. dan A. I. (2013). Energi Alternatif Untuk Indonesia di Masa Depan. Penelitian Masalah Lingkungan Di Indonesia, 269-277. $\quad$ Retrieved from https://www.scribd.com/document/356326787/p-Energi-Alternatif-Untuk-Indonesia-Di-Masa-Depan

Musanif, J. I. W. A. A. dan D. M. N. (2006). Program Bio Energi Pedesaan-Biogas Skala Rumah Tangga. Ditjen Pengolahan Dan Pemasaran Hasil Pertanian Departemen Pertanian.

Pearce, J. and Robinson, R. (1998). Strategic Management. New York: Irwin McGraw Hill/Irwin.

Priyadi, F. dan E. S. (2016). Studi Potensi Biogas dari Kotoran Ternak Sapi sebagai Energi Alternatif untuk Penerangan. Proceeding Seminar Nasional Inovasi Dan Rekayasa Teknologi, 53-60. Cirebon: Universitas 17 Agustus 1945 (UNTAG ’45).

Putro, S. (2007). Penerapan Instalasi Sederhana Pengolahan Kotoran Sapi Menjadi Energi Biogas di Desa Sugihan Kecamatan Bendosari Kabupaten Sukoharjo. Warta, 10 (2), 178-188.

Purbowati, E., C.I. Sutrisno, E. Baliarti, S.P.S. Budhi dan W. Lestariana. 2006. Komposisi kimia otot Longissimus dorsi dan Biceps femoris domba lokal jantan yang dipelihara di pedesaan pada bobot potong yang berbeda. Journal Animal Production, 8(1), 1-7

Rangkuti, F. (2013). Teknik Membedah Kasus Bisnis Analisis SWOT Cara Perhitungan Bobot, Rating, dan OCAI. In PT. Gramedia Pustaka Utama. Jakarta. Retrieved from http://oaji.net/articles/2015/19371429848752.pdf

Renosori, P. (2012). Kajian Peningkatan Pemanfaatan Kotoran Sapi Menjadi Biogas dengan Metoda SWOT dan AHP di Desa Wangunsari Kecamatan Lembang. Jurnal Buana Sains, 12 (1), 109-116.

Sagala. (2000). Peran Energi Dalam Pembangunan Nasional Memasuki Milenium. Widyanuklida, 3 (1), 1-5.

Said, S. (2008). Membuat Biogas dari Kotoran Hewan. Jakarta: Indocamp.

Sarwanto, D. (2004). Model Pencemaran Limbah Peternakan Sapi Perah Rakyat pada Beberapa Kondisi Fiik Alami dan Sosial Ekonomi (Studi Kasus di Propinsi Jawa Tengah). Institut Pertanian Bogor. 
Ningrum, dkk : Analisis Strategi Pengembangan Biogas Sebagai Energi Alternatif Rumah Tangga Dengan

Sofyan, P. U. (2008). Strategi Pengembangan Biodiesel Berbasis Tanaman Jarak Pagar Pada PT. Armada Indonesia Sukabumi. Institut Pertanian Bogor.

Soleh, J. (2009). Strategi Pengembangan Usaha Ternak Sapi Perah di Kecamatan Sukaresmi Kabupaten Cianjur Jawa Barat. Institut Pertanian Bogor.

Sudiarto, B. (2008). Pengelolaan Limbah Peternakan Terpadu dan Agribisnis yang Berwawasan Lingkungan. Prosiding Seminar Nasional Teknologi Peternakan Dan Veteriner, 52-60. Bandung: Universitas Padjajaran.

Sugiyono. (2013). metodologi penelitian kuantitatif kualitatif dan R \& D. In Bandung: Alfabeta. https://doi.org/10.1164/rccm.200409-1267OC

Sukarsono, A. (2011). Sistem Produksi Biogas Yang Terintegrasi (Sebuah Aplikasi Teknologi Tepat Guna Melalui Pemanfaatan Limbah). Cybertechn, 5 (2), 29-34.

Tantalo, S. (2010). Perbandingan Performance Dua Strain Broiler yang Mengonsumsi Air Kunyit. Jurnal Penelitian Pertanian Terapan, 10(3), 200-2016.

Teguh W.W., 2007, Teknologi Biogas Dan Aplikasinya Untuk Masyarakat Pedesaan. Makalah disampaikan Pada Temu Komunikasi Dan Praktek Pemecahan Masalah Sektor Peternakan. Jakarta: Badan Litbang Partanian Departemen Pertanian.

Wahyuni, S. (2008). Analisis Kelayakan Pengembangan Biogas Sebagai Energi Alternatif Berbasis Individu dan Kelompok Peternak. Institut Pertanian Bogor.

Wahyuni, S., \& Saleh, A. (2009). Analisis Kelayakan Pengembangan Biogas Sebagai Energi Alternatif Berbasis Individu Dan Kelompok Peternak. Manajemen IKM, 4(2), 217-224. Retrieved from swenitrans@yahoo.com

Widyastuti, F.R., \& Purwanto, H. (2013). Potensi Biogas Melalui Pemanfaatan Limbah Padat Pada Peternakan Sapi Perah Bangka Botanical Garden Pangkal Pinang. Jurnal METANA, 9 (2), 19-26.

Yusuf, M. S., \& Efrita, A. (2014). Pemanfaatan Kotoran Ternak Sebagai Energi Alternatif Untuk Pembangkit Listrik Tenaga Biogas Di Desa Nongkojajar, Kabupaten Pasuruan. Prosiding Seminar Nasional Sains Dan Teknologi Terapan, 638-648. Surabaya: Institut Teknologi Adhi Tama Surabaya. 